\title{
Ścisła pamięć o Zagładzie w Muzeum Historii Holokaustu w Yad Vashem. Odpowiedź na artykuł Amosa Goldberga
}

Choć w swoim artykule (Czy w Nowym Muzeum Historii Zagłady Yad Vashem znajdziemy „Innego”?) Amos Golberg wyraża swój podziw dla Yad Vashem jako instytucji badawczej i oświatowej, to jednak chciałby, aby nasze Nowe Muzeum Historii Zagłady było zupełnie inne. Jego zaskakujące „obserwacje” i wnioski dotyczące tego, co rzekomo tam „jest” i czego tam „nie ma”, wydają się odnosić do całkiem innego miejsca, a z pewnością nie do muzeum, którego projekt nasza instytucja przez wiele lat skrupulatnie planowała i wprowadzała w życie.

W swojej obszernej krytyce Nowego Muzeum Historii Zagłady Goldberg opiera się na interpretacji wydarzeń w szerokim kontekście współczesnej pamięci o Zagładzie i jej miejsca w kulturze i polityce Zachodu. Uważa on, że muzeum za dużo uwagi poświęca historii samego Holokaustu i udziałowi Żydów w tym wydarzeniu. Goldberg proponuje uniwersalizację narracji muzeum i włączenie do niej innych zjawisk i kwestii, a także ofiar nie tylko nazistów, ale i innych tragicznych epizodów w historii XX w. Postulat uniwersalnej ludzkiej identyfikacji z Holokaustem nie jest ani czymś niespotykanym, ani niegodnym. Niespotykane i niegodne jest natomiast stwierdzenie, że muzeum Yad Vashem stanowi przeszkodę na drodze do tejże identyfikacji.

Goldberg uogólnia swoje indywidualne odczucia po wizycie w muzeum na wrażenia milionów ludzi z całego świata, którzy odwiedzili je od chwili otwarcia, tj. od 15 marca 2005 r. Podobnie jak wielu zwiedzających, Goldberg chciałby wynieść zeń spotęgowaną wersję tego, co do niego wniósł. Wydaje się wielce rozczarowany tym, że muzeum nie spełnia pokładanych w nim nadziei, czyli że nie potwierdza jego własnego poglądu ideologicznego na Zagładę i współczesną historię Zachodu. Zawód ten może pomóc wyjaśnić jego wybiórczy odbiór dużej części muzeum.

Posługując się nieskrywanymi oskarżeniami bądź insynuacjami, Goldberg porusza wiele kwestii, do których nie jesteśmy w stanie odnieść się w tym tekście. Dlatego też w tej odpowiedzi skupimy się na kilku głównych zarzutach.

Na pierwszy plan wysuwa się stwierdzenie, jakoby muzeum lansowało zawężoną, skoncentrowaną na Żydach wizję Zagłady - mityczną pod względem historycznym i ślepą na punkt widzenia oraz doświadczenia „innych”. Spośród aktorów 
Zagłady Goldbergowi najbardziej brakuje „uczestników” (jest to oczywista i zagadkowa aluzja do sprawców), których nieobecność sprawia ponoć, że muzeum przedstawia „czyny bez sprawców”.

Goldberg stwierdza też, że „Zagładzie przedstawionej w taki sposób, jak to zrobiono w muzeum, brakuje ziemskiego wymiaru”. Ów „fakt”, spotęgowany tym, że Zagłada zajmuje centralne miejsce w świadomości Zachodu, a nawet całej ludzkości, według Goldberga powoduje przekształcenie Zagłady w odległe, nierzeczywiste wydarzenie „z innej planety” (by użyć znanego zwrotu ukutego przez pisarza ocalałego z Zagłady, Yehiela De-Nura). Twierdzi on, że z tego względu zwiedzający przestają odczuwać potrzebę głębokiej kontemplacji i introspekcji, dzięki czemu nawet rodacy sprawców Zagłady i innych aktów ludobójstwa mogą uczestniczyć w czymś, co w rzeczywistości jest zakłamanym, pustym aktem pseudoupamiętnienia, służącym własnym interesom Żydów.

Zdumiewające jest to, że szukając dowodów rzekomych wad naszego muzeum, Goldberg porusza kwestię wymiernego sukcesu instytucji, tj. jej ogromnej popularności. Sam fakt, że ściągają tu rzesze ludzi, z których wielu przez długi czas wspomina, jak bardzo wizyta ta wpłynęła na ich życie, jest dla Amosa Goldberga prawie niezaprzeczalnym dowodem klęski muzeum.

Zanim wykażemy błędy w jego stwierdzeniach i odbiorze muzeum, musimy zaznaczyć, że żadne muzeum, nawet Yad Vashem, nie jest, bo nie może być doskonałe. Jesteśmy otwarci na komentarze, sugestie zmian i krytykę, a nawet okresowo inicjujemy ocenę skuteczności naszych programów, personelu i obiektów. Prawdę mówiąc, od chwili otwarcia muzeum wystawa uległa pewnym zmianom. Oczywiście, do przeprowadzenia każdej ewaluacji czy zmiany potrzeba przede wszystkim bezstronności, obiektywizmu i pełnej znajomości tematu.

Niestety, argumenty Goldberga opierają się na świadomym lub będącym wynikiem zaniedbania pominięciu aż połowy wystawy Nowego Muzeum Historii Zagłady. Jest oczywiste, że założeniem muzeum jest opowiedzenie historii Zagłady z perspektywy jej ofiar żydowskich. Ma ono przywrócić Żydom należne im miejsce w dziejach, którego naziści usiłowali im odmówić i do której to odmowy od tamtych czasów nieświadomie nakłaniało zbyt wielu naukowców, jak też liczne muzea i miejsca pamięci. Niemniej muzeum wytrwale i systematycznie opowiada także o czynach nazistów i ich sojuszników. Znaczna część wystawy poświęcona jest jednym i drugim, a ciąg wydarzeń zapoczątkowanych i wywołanych przez reżim nazistowski stanowi szkielet planu chronologicznego narracji. W rzeczy samej, muzeum przedstawia wieloaspektową relację z Zagłady i sprawia, że odwiedzający styka się ze wszystkimi jej ludzkimi aktorami, bez względu na to, jak nieludzkie były ich poczynania, dlatego że właśnie ich człowieczeństwo zmusza nas wszystkich do potraktowania tego tematu jako prawdziwego, współczesnego i bardzo ziemskiego.

„Sprawcy” są obecni w muzeum, podkreślającym ludzkie zachowanie i ewidentnie niezainteresowanym tym, co mityczne. Dlatego też tak dużo uwagi poświęcono jednostkom - różnym Żydom, sprawcom narodowości niemieckiej i nie tylko, których pochodzenie i losy omówiono w czarnych witrynach zawieszonych 
na wysokości wzroku w większej części wystawy. Duży fragment całej ekspozycji dotyczy Sprawiedliwych wśród Narodów Świata. Filmy, fotografie i podpisy znajdujące się w całym Muzeum składają się na szeroki obraz tła historycznego i perspektywy historycznej procesów i wydarzeń mających bezpośredni i pośredni wpływ na przebieg Zagłady.

W muzeum znajduje się 110 ekranów, na których wyświetlamy około dwunastu godzin filmów. Większość z nich traktuje o ocalałych, przywołujących różne aspekty swoich losów i zmagań z czasów Zagłady i w bezpośrednim jej wyniku. W interakcji jednostki z szerszą narracją zwiedzający dosłownie staje twarzą w twarz ze sprawcami, Żydami i Sprawiedliwymi, poznaje wybory i czyny, których dokonywali, i dylematy, przed którymi stawali. W swoim człowieczeństwie wzywają oni zwiedzających do refleksji nad ludzkimi czynami i odpowiedzialnością. Nie jawią się oni jako potwory z innej planety lub mitologiczni herosi na piedestale. Wręcz odwrotnie: poznajemy ich jako istoty ludzkie z właściwymi im mocnymi stronami i słabościami, jako ludzi, którzy w krytycznych chwilach podjęli pewne decyzje i wybrali określony sposób postępowania. Niezliczeni goście muzeum - wśród nich młodzież, nauczyciele, duchowni i mężowie stanu - dostrzegli, że właśnie to przesądza o głębokich uniwersalnych implikacjach i znaczeniu instytucji oraz że w tym zabiegu zawierają się ważne pytania i wyzwania skierowane do wszystkich bez względu na pochodzenie. Wydaje się, że w przeciwieństwie do innych Amos Goldberg nie umie lub nie chce tego zrozumieć. Ta właśnie specyfika muzeum i całego Yad Vashem była głównym powodem, dla którego delegacja z Ruandy postanowiła odwiedzić naszą instytucję w 2006 r., by korzystając z naszych spostrzeżeń i doświadczeń, wyciągnąć naukę na potrzeby kontekstu ruandyjskiego.

Gdyby Goldberg uznał niewątpliwe wysiłki muzeum podejmowane w celu „uczłowieczenia” głównych uczestników i wydarzeń Zagłady i pokazał, dlaczego te wysiłki nie przynoszą efektu, mogłaby wywiązać się z tego sensowna dyskusja. Goldberg natomiast zupełnie ignoruje ten główny aspekt muzeum, czym wprawia nas w konsternację.

Nie wspomina też o sali refleksji na końcu trasy zwiedzania. Zgadzamy się, że „przyjąwszy taki punkt wyjścia [bezprecendensowość i wyjątkowość Zagłady], pragnie się wyjaśnienia, wypełnienia pustej przestrzeni «niedowierzania»: jak do tego doszło?” Dlatego też jesteśmy zaskoczeni, że historyk taki jak Goldberg dodaje: „Co zaskakujące, muzeum całkowicie unika tego pytania”. Stwierdzenie to stoi w jawnej sprzeczności z faktem, że na końcu trasy zwiedzania znajduje się słynna sala zaprojektowana specjalnie jako miejsce wstępnej refleksji, wiemy bowiem, iż zwiedzający zadają takie pytania, do czego też ich zachęcamy. Co więcej, Goldberg ma świadomość, że te sala jest p i e r w s z y m miejscem kontemplacji w Yad Vashem po zwiedzeniu wystawy, ale z pewnością nie ostatnim ani jedynym. W przylegającym do muzeum ośrodku edukacyjnym zwiedzający moga postawić sobie wiele ważkich pytań nasuwających się po zetknięciu się z przemyśleniami i analizami ocalałych, przywódców religijnych, pisarzy, artystów, historyków oraz wielu innych uczonych i myślicieli z całego świata. Zarówno ośrodek, jak i nasza 
równie przełomowa filmoteka, ikoniczny Pomnik Dzieci, Aleja Sprawiedliwych, Dolina Zabitych Wspólnot oraz inne pomniki i miejsca na Górze Pamięci zadaja kłam nieszczerym twierdzeniom Goldberga.

Kolejny aspekt jego krytyki odnosi się do tego, czego w muzeum rzekomo n i e $\mathrm{m}$ a. Goldberg stale podkreśla, że kluczowe kwestie, takie jak ważne wydarzenia sprzed 1933 r., proces eskalacji i wykrystalizowania się planu „ostatecznego rozwiązania” nie zostały „wyjaśnione”. Na poparcie tego zarzutu Goldberg porównuje nasze przedstawienie rozwoju planu „ostatecznego rozwiązania” z tym zawartym w doskonałej, wyczerpującej książce The Origins of the Final Solution Christophera R. Browninga, napisanej na zamówienie Yad Vashem. „Jak widać, Yad Vashem uznaje więcej niż jedną [narrację]” - dodaje Goldberg. Zaskakujące, że historyk ocenia wystawę muzealną, używając kryteriów odpowiednich do oceny dogłębnej, 600-stronicowej monografii, tym bardziej że kilka stron wcześniej sam stwierdził, iż „muzeum to nie podręcznik historii”. Wystawa muzealna oczywiście nie może, a nawet nie powinna poruszać każdego aspektu każdej kwestii. Intuicja podpowiada nam, że teksty wystawy, zwłaszcza w muzeach historycznych, muszą być wystarczająco zwięzłe i proste, tak by przeciętny odwiedzający mógł przyswoić najważniejsze punkty narracji danego muzeum. Opowieść naszej wystawy zasadza się na wyczerpujących badaniach naukowych, ale dołożyliśmy wszelkich starań, by uniknąć jałowych dłużyzn i zawiłości. Czy zwiedzający, który jakimś cudem zdołałby (w ciągu godziny lub dwóch) zapoznać się z obszernymi fragmentami tekstów i nagraniami filmowymi zasugerowanymi przez Goldberga, naprawdę „zrozumiałby” Zagładę - temat, któremu uniwersytety poświęcają całe semestry zajęć?

Pomyślany jako całkowicie odmienny od innych pomników Zagłady, instytut Yad Vashem w sensie instytucjonalnym od początku łączył w sobie szeroki wachlarz dziedzin i funkcji: zajmował się dokumentacją, badaniami, edukacją, działalnością wydawniczą, upamiętaniem itd. Nowe Muzeum Historii Zagłady jest tylko j e d n ą z części składowych Yad Vashem. Sam Goldberg pochlebnie wypowiada się o pozostałych działach muzeum. Niemniej dla własnej wygody chwali je tylko na początku artykułu, by potem całkowicie wykluczyć je z dyskusji, zupełnie jakby nie istniały i nie były częścią sfery oddziaływania koncepcji muzeum.

Weźmy na przykład wydawnictwo Yad Vashem. Od otwarcia nowego kompleksu muzealnego sprzedaż naszych publikacji wzrosła pięciokrotnie. Do najchętniej kupowanych pozycji należą studia historyczne, z których wiele trafia do rąk zwiedzających. Skoro goście muzeum nabywają takie publikacje historyczne, można zaryzykować stwierdzenie, że wbrew opinii Goldberga inspiruje ono zwiedzających do zadawania historycznych i egzystencjalnych pytań o Zagładę. Co więcej, jak sam może poświadczyć, wielu gości zwiedza muzeum w grupach uczestniczących w wykładach, seminariach i wycieczkach uzupełniających w naszej Międzynarodowej Szkole Nauczania o Holokauście. W takich pogłębiających wiedzę programach, trwających od jednego dnia do kilku tygodni, bierze udział ponad jedna czwarta zwiedzających (z czego jedna trzecia to obcokrajowcy). 
Opinie gości zebrane w ciągu ostatnich sześciu lat działalności muzeum potwierdzają przekonanie Yad Vashem o tym, że wizyta w naszej instytucji jest dla większości zwiedzających głębokim doświadczeniem intelektualnym i moralnym, zachęcającym do zgłębiania tematu i zrozumienia genezy Zagłady oraz jej następstw. Muzeum nie „bazuje na autorytatywnym, niczego niewyjaśniającym opisie”. Wręcz odwrotnie, zachęca zwiedzających do pogłębiania wiedzy i podjęcia autentycznego dialogu z bolesnymi kartami historii Zagłady.

Narracja Muzeum to nie jedyny aspekt omawiany przez Goldberga, przy którym robi on dość oczywiste aluzje do nadmiernego autorytaryzmu. Jego błędny opis położenia i projektu architektonicznego muzeum - jak „imperialny” lub „autorytarny” może być budynek położony prawie w całości pod ziemią i niewidoczny z jej powierzchni? - jest niezgodny ze stanem faktycznym. Istnieje prawdopodobieństwo, że czytelnik, który nie widział Yad Vashem, dojdzie do groźnego wniosku, iż Nowe Muzeum Historii Zagłady i jego otoczenie tworzą niby to faszystowski kompleks, co pozwala manipulować zwiedzającymi. Ta oszczercza insynuacja jest nie tylko absurdalna, ale też raczej niespotykana wśród licznych i zróżnicowanych międzynarodowych reakcji na nowe muzeum.

Wielkim wyzwaniem stojącym przed każdym projektantem poważnego muzeum o Zagładzie, a przed którym Goldberg się uchyla, jest kwestia zdefiniowania „Zagłady” lub przynajmniej określenia zakresu tego terminu. Jest to oczywiście warunek wstępny do ustalenia sposobu przedstawienia tematu. Podczas projektowania muzeum Yad Vashem z pewnością zastosowano tę zasadę.

Definicja terminu „Zagłada” czy „Szoa” różni się w zależności od kraju. Niektórzy uważają go za synonim nazistowskiego terminu „ostateczne rozwiązanie kwestii żydowskiej”. Większość poważnych historyków odrzuca taką perspektywę, zawężającą ramy tego wydarzenia historycznego. Z pewnością nie jest akceptowana w Izraelu, gdzie terminu „Szoa” używa się od lat czterdziestych. Termin „Zagłada”/,Szoa” obejmuje tutaj pełne spektrum prześladowań Żydów przez cały okres nazizmu ze strony nazistów i ich sojuszników oraz pełny wachlarz reakcji Żydów i innych ofiar.

Od lat osiemdziesiątych z związku z rosnącą świadomością Zagłady na Zachodzie międzynarodowy dyskurs w coraz większym stopniu skojarzył inne grupy ofiar (na przykład Sintich i Romów, homoseksualistów, komunistów i osoby upośledzone umysłowo) z wojennym losem Żydów i włączył je w znaczenie terminu „Zagłada”. Oczywiście ofiarami prześladowań reżimu nazistowskiego padło wiele jednostek i grup, a śmierć każdej z tych ofiar zawsze miała taką samą wagę: morderstwo to morderstwo.

Niemniej z historycznego punktu widzenia prześladowania i mordowanie Żydów od chwili dojścia Hitlera do władzy w 1933 r. były czymś wyjątkowym. Do takich właśnie wniosków doszła większość historyków tego okresu, których ważne badania legły u podstaw narracji muzeum. Mowa tu o czołowych badaczach, takich jak Yehuda Bauer, Christopher R. Browning, Saul Friedländer, Israel Gutman (doradca ds. projektu historycznego muzeum), Ian Kershaw i inni. Ideologia na- 
rodowosocjalistyczna i ucieleśniający ją reżim nazistowski postrzegały wszystkie nieżydowskie grupy prześladowanych jako zagrożenie dla pewnego aspektu „zdrowego życia” Niemiec. W związku z tym ze względów pragmatycznych w stosunku do nich naziści byli skłonni do ustępstw lub nawet do tymczasowego zaprzestania prześladowań.

Natomiast w s z y s t k i c h Żydów uważano za nosicieli destrukcyjnego, niedającego się wyplenić „żydowskiego ducha”, stanowiącego niewyobrażalne zagrożenie, które należało wyeliminować. Właśnie ta ideologia i oparta na niej polityka Niemiec nazistowskich i ich sojuszników sprawiła, że współczesna cywilizacja zatrzęsła się w posadach. Yad Vashem od zawsze zmierza do wyjaśnienia tej kwestii, a krytyka samego Goldberga dowodzi, jak potrzebne stały się te starania. Nowe Muzeum Historii Zagłady Yad Vashem przedstawia zatem prześladowania Żydów od 1933 r. jako wspólny cel nazistów, do którego dążyli z coraz większą energią, początkowo mało konkretny i doprecyzowany dopiero później. Wobec tego nasuwa się pytanie: „Dlaczego Żydzi?”. Właśnie dlatego już na początku wystawy pojawiają się krótkie teksty o antysemityzmie. Ekspozycja ma na celu należyte przedstawienie doświadczenia Żydów w okresie, gdy prześladowania przybierały na sile. W rezultacie zwiedzający ma zastanowić się na tym, jak mogło do tego wszystkiego dojść. Po wyczerpującej i żmudnej prezentacji różnych etapów i aspektów Zagłady trasa zwiedzania kończy się dwoma pomieszczeniami, gdzie zwiedzający mają oddać się refleksji. Jesteśmy przekonani, że ta narracja holokaustowa nie przesłania ani nie umniejsza ogromu prześladowań i cierpień innych. Wierzymy, że zamiast tego skupia obecną uwagę zwiedzających na konkretnym, okrutnym i ostatecznym w swej istocie prześladowaniu, którego obraz w przeciwnym wypadku mógł ulec wypaczeniu.

Goldberg twierdzi, że Yad Vashem wraz z pewnymi innymi ważnymi muzeami stanowi przykład współczesnej tendencji w krajach Zachodu do umieszczania ofiary w centrum zainteresowania. Czyżby? Choć muzeów Zagłady jest dziś wiele, tylko kilka z nich naprawdę skupia się na ofiarach. Widać to zwłaszcza na przykładzie instytucji ujmujących Zagładę w niejednoznaczne ramy ludobójstwa, totalitaryzmu i praw człowieka. Aby określić wspólny wyznacznik różnych przypadków mordów, muzea te muszą, celowo czy nie, umniejszyć znaczenie złożonych procesów historycznych i zamiast tego skupić się na pewnego rodzaju wymiarze psychologicznym. Czynią to w dobrej wierze, by zapobiec przyszłym okrucieństwom. Niestety, tym samym rezygnują z wierności prawdzie historycznej i podają w wątpliwość własną rzetelność.

Amos Goldberg chciałby, żeby celem Yad Vashem było raczej „prawdziwe oddanie wartościom takim jak prawa człowieka i wolność” niż odnoszenie się do konkretnych Żydów, Niemców i kolaborantów w konkretnym czasie i miejscu. Pozostaje ślepy na fakt, że oba te cele wcale nie są ze sobą sprzeczne. Wręcz przeciwnie, Nowe Muzeum Historii Zagłady Yad Vashem wydaje się stać na stanowisku i wykazywać, że najbardziej efektywnymi środkami inspirowania i kultywowania uniwersalnej moralności humanistycznej są skoncentrowane, wierne faktom 
przedstawienia konkretnych ludzkich doświadczeń i zjawisk, po zapoznaniu się z którymi następuje szczera kontemplacja i swobodny, otwarty dyskurs.

Pomimo swojego humanistycznego i uniwersalistycznego dementi Goldberg wolałby widzieć muzeum niejasne - i w konsekwencji dezorientujące - manipulujące odwiedzającymi, opierające się na „politycznie poprawnych”, lecz płytkich, zmiennych programach publicznych. Takich instytucji jest już wystarczająco wiele. Zapraszamy czytelników do wizyty w Yad Vashem i doświadczenia, jak wygląda realne rozwiązanie alternatywne wobec nich.

Z języka angielskiego przełożyła Anna Brzostowska

\title{
Słowa kluczowe
}

Muzeum Yad Vashem, narracje o Zagładzie

\begin{abstract}
A polemic text toward Amos Goldberg's Is there an "Other" in this (Yad Vashem New Holocaust) Museum?
\end{abstract}

\section{Key words}

Yad Vashem Museum, Holocaust narrations 